\title{
Correspondence
}

http://dx.doi.org/10.11646/phytotaxa.167.1.11

\section{New synonyms for South American/Brazilian Pottiaceae (Bryophyta)}

\author{
DENISE PINHEIRO DA COSTA ${ }^{1}$
}

${ }^{1}$ Research Institute of Rio de Janeiro Botanical Garden, Rua Pacheco Leão $n^{\circ}$ 915, 22460-030, Rio de Janeiro, RJ, Brazil, e-mail:dcosta@jbrj.gov.br

\begin{abstract}
During a taxonomic review of Pottiaceae in Brazil, five new synonyms were discovered for species in the genera Hyophila, Pseudosymblepharis, and Weissia.
\end{abstract}

Key words: Brazil, Hyophila, Pseudosymblepharis, Weissia, Pottiaceae, taxonomy

\section{Introduction}

In an attempt to solve taxonomic problems concerning Pottiaceae of Brazil, a taxonomic review found that five new synonyms were required for species in the genera Hyophila Bridel (1827:760), Pseudosymblepharis Brotherus (1924:261), and Weissia Hedwig (1801:64). The family Pottiaceae includes five subfamilies, six tribes, 77 genera and 1457 species in the world (Zander 1993), being considered the largest family of mosses in the Neotropics. The Pottiaceae are represented in the Neotropics by 55 genera and ca. 360 species (Gradstein et al. 2001). About six subfamilies, 33 genera, and 63 species of Pottiaceae are recognized for Brazil (Costa 2011, Costa 2013).

The Brazilian taxa are found in open, often rather dry localities, with the greatest diversity occurring in the mountainous regions, 500-1500 m. The habitats of the Pottiaceae species in Brazil are diverse, but generally are extreme, involving such pressures as desiccation and disturbance, sometimes associated with human activities.

Crosby et al. (1999) listed 1356 species for Pottiaceae in the world, of which 601 are considered insufficiently known from a taxonomic point of view. Thus, Pottiaceae includes a large number of insufficiently known species, and, in most cases, with knowledge limited to their original description. Several genera, e.g., Barbula Hedwig (1801:115), Tortula Hedwig (1801:122), Trichostomum Bruch (1829:396), Weissia Hedwig (1801:64) present in Brazil are considered problematic and need a regional revision that will likely result in a significant reduction in the number of species recognized.

\section{Material \& methods}

The investigation is based on the study of types and collections from the following herbaria: BM, H-BR, MG, NY, PC, $\mathrm{R}, \mathrm{RB}, \mathrm{SP}$. Specimens were investigated using light microscopy.

\section{Taxonomy}

1. Hyophila involuta (Hook.) A.Jaeger, Ber. Thätigk. St. Gallischen Naturwiss. Ges. 1871-72: 354. 1873 (Jaeger 1873). 


\section{Acknowledgements}

I express my gratitude to the curators of the herbaria (BM, H-BR, MG, NY, R, SP) for the loan of specimens. This research was funded by the Conselho Nacional de Desenvolvimento Científico e Tecnológico (CNPq) for the productivity and undergraduate grants.

\section{References}

Allen, B.H. (2002) Moss Flora of Central America Part.2 Encalyptaceae. Monographs in Systematic Botany from the Missouri Botanical Garden. 90: 1-699.

Bridel, S.E. (1827). Bryologia Universa 1: 747-856.

Brotherus, V.F. (1900) Die Laubmoose der ersten Regnellschen Expedition. Bihang til Kongliga Svenska Vetenskaps-Akademiens Handlingar26 Afd. 3(7): 1-65.

Brotherus, V.F. (1924) Musci (Laubmoose). Ergebnisse der botanische Expedition der Kaiserlischen Akademie der Wissenschaften nach Sudbrasilien 1901. Band II (Thallophyta et Bryophyta). Pp. 251-358.

Bruch, P. (1829) Flora 12: 385-396.

Costa, D.P. (2013) Pottiaceae. In: Lista de Espécies da Flora do Brasil. Jardim Botânico do Rio de Janeiro. http://floradobrasil.jbrj.gov. br/jabot/floradobrasil/FB95862).

Costa, D.P., Pôrto, K.C., Luizi-Ponzo, A.P., Ilkiu-Borges, A.L., Bastos, C.J.P., Câmara, P.E.A.S., Peralta, D.F., Bôas-Bastos, S.B.V., Imbassahy, C.A.A., Henriques, D.K., Gomes, H.C.S., Rocha, L.M., Santos, N.D., Siviero, T.S., Vaz-Imbassahy, T.F. \& Churchill, S.P. (2011) Synopsis of the Brazilian moss flora: checklist, distribution and conservation. Nova Hedwigia 93: 277-334. http://dx.doi.org/10.1127/0029-5035/2011/0093-0277

Crosby, M.R., Magill, R.E., Allen, B. \& He, S. (1999) A Checklist of the Mosses. Missouri Botanical Garden, St. Louis.

Crum, H.A. (1952) Pseudosymblepharis in Middle America. The Bryologist 55: 137-142. http://dx.doi.org/10.2307/3240202

Gradstein, S.R., Churchill, S.P. \& Salazar-Allen, N. (2001) Guide to the Bryophytes of Tropical America. Memoirs of the New York Botanical Garden 86: 1-577.

Grout, A.J. (1938) Moss Flora of North America 1: 1-264.

Hampe, E. (1879) Enumeratio muscorum hactenus in provinciis Brasiliensibus Rio de Janeiro et São Paulo detectorum. Videnskabelige Meddelelser fra dansk naturhistoriske Forening i Kjöbenhavn 26: 73-164.

http://dx.doi.org/10.5962/bhl.title.4410

Hedwig, J. (1801) Species muscorum frondosorum descriptae et tabulis aeneis coloratis illustrate. Leipzig. http://dx.doi.org/10.5962/bhl.title.26

Hooker, W.J. (1820) Musci Exotici 2: 154. http://dx.doi.org/10.5962/bhl.title.10721

Jaeger, A. (1873) Bericht über die Thätigkeit der St. Gallischen Naturwissenschaftlichen Gesellschaft 1871-72: 354 (Gen. Sp. Musc. 1: 202).

Müller, C. (1849) Synopsis Muscorum Frondosum 1: 664.

Müller, C. (1857) Beitrage zu einer Flor der Kryptogamen Brasiliens, insbesondere der Insel Santa Catharina. Botanische Zeitung 15: 382.

Paris, E.G. (1894-1898) Index Bryologicus sive Enumeratio muscorum hucusque cognitorum adjunctis synonymia distributioneque geographica locupletissimus /quem conscripsit E.G. Paris. 1879 pp. http://dx.doi.org/10.5962/bhl.title.643

Zander, R.H. \& (1987) A new species of Tuerckheimia from Mexico. Memoirs of the New York Botanical Garden 45: 293-295.

Zander, R.H. (1993) Genera of the Pottiaceae: Mosses of harsh environments. Bulletin of the Buffalo Society of Natural Sciences 32: $1-378$. 